\title{
Impacts of Norway spruce (Picea abies L., H. Karst.) stands on soil in continental Croatia
}

\author{
Ivan Perković, \\ Nikola Pernar, \\ Vibor Roje, \\ Darko Bakšić, \\ Matej Baneković
}

\begin{abstract}
A quantitative analysis of pedo-physiological indicators aimed at determining changes in the soil attributable to the effects of spruce plantations was done. The study was conducted at eight sites in central and north-western Croatia where spruce plantations were planted in the late $20^{\text {th }}$ century. At each site, a pedological profile was opened within the spruce plantation and the endomorphological parameters of the soil were determined. Composite soil samples from two depths $(0-10 \mathrm{~cm}$ and $10-20 \mathrm{~cm})$ and from the forest floor were taken in the spruce plantation and compared with samples taken at plots covered by natural vegetation (natural stands) located in the surroundings. The following pedo-physiographic indicators were measured on the collected soil samples: quantity of forest floor, particle size distribution of soil, $\mathrm{pH}$ values in $\mathrm{H}_{2} \mathrm{O}$ and in $\mathrm{CaCl}_{2}$ aqueous solution (concentration $0.01 \mathrm{~mol} \mathrm{dm}^{-3}$ ), content of $\mathrm{C}_{\text {org }}$, content of $\mathrm{N}_{\text {tot }}$ and content of bioavailable nutrients (using the Mehlich III method). The results showed that the forest floor had a higher mass in the spruce plantations than in natural stands. The mineral soil showed clear trends of influence of the spruce plantations on soil in terms of reduced $\mathrm{pH}$ values. Most plots in the spruce plantations showed a lower nitrogen content in the soil, a higher $\mathrm{C} / \mathrm{N}$ ratio and lower content of bioavailable phosphorus. This study provides an insight into the amelioration effects of spruce plantations on soil, and represent a reliable basis for decision-making in planning specific interventions in terrestrial ecosystems, such as the establishment of new forest plantations.
\end{abstract}

Keywords: Spruce Plantation, Forest Soil, Chemical Properties of Soil, Forest Floor

species, tipically when planted in a monoculture, have varying impacts on soil (Klimo 2000). The specificity of such impacts is associated with the nature of the tree species, in terms of the quality and quantity of the organic matter participating in humus production, nutrient cycling, fertility maintainance and ecological stability of the forest ecosystem (Augusto et al. 2002, Mareschal et al. 2010, Kostić et al. 2016), leading to a modification of local microclimate and pedoclimate. Furthermore, the specific influences of vegetation on soil are associated with the macroclimatic conditions which will determine the production of organic matter and the dynamics of its humification and mineralisation (Berg \& McClaugherty 2008). For these reasons, forest ets) into productive stands (Oršanić et al. 2000). Research has shown that certain

University of Zagreb, Faculty of Forestry, Svetošimunska cesta 25, 10002 Zagreb (Croatia)

@ Ivan Perković (iperkovic@sumfak.hr)

Received: Dec 13, 2018 - Accepted: Aug 26, 2019

Citation: Perković I, Pernar N, Roje V, Bakšić D, Baneković M (2019). Impacts of Norway spruce (Picea abies L., H. Karst.) stands on soil in continental Croatia. iForest 12: 511-517. doi: 10.3832/ifor3023-012 [online 2019-12-02]

Communicated by: Giustino Tonon plantations can significantly modify physical and chemical properties of soil and soil processes (Moukoumi et al. 2006). Berger \& Berger (2012) stated that coniferous tree species, due to the compounds in needles that take longer to decompose, slow nutrient cycling and microbiological activity, which leads to a lowering of soil pH. Previous research has shown that planting with conifers results in an increased stock of organic carbon in the soil (Vesterdal et al. 2008), lower $\mathrm{pH}$ values and changes in the content of carbon and nitrogen in soil (Binkley \& Valentine 1991, Perković et al. 2007). Most studies on soil impacts have been conducted on natural and planted stands of Norway spruce (Lesná \& Kulhavy 2003, Klimo \& Kulhavy 2006, Galvan et al. 2008), since this is the most common species used in forest plantations of continental Europe. In particular, research during the last decades has focused on soil acidification and the reduced stand vitality resulting from climate change. At elevations less than $900 \mathrm{~m}$ a.s.l., spruce stands often contribute to the development of district cambisol and podzolic soils, e.g., soils with acidic to very acidic reactions that are relatively poor in nutrients (Berger et al. 2004, Penízek \& Zádorova 2012).

This study is based on the knowledge from the Central European spruce mono- 
cultures, which are currently affected by problems including massive diebacks. This has been associated with aero-pollution, soil acidification, bark beetle outbreaks, fungal diseases, etc. The objectives of this study were: (i) to examine the overall effects of spruce plantations on soil and to determine possible unfavourable effects of the tree species (Norway spruce) on soil; (ii) to examine the quantitative indicators of soil physiography in order to determine the soil changes that could be attributed to spruce plantations, and to evaluate the significance of such changes.

\section{Material and methods}

\section{Study area}

Eight localities were selected in central and north-western Croatia (Tab. 1, Fig. 1) where spruce plantations have been established during the latter half of the $20^{\text {th }}$ century within the vegetation belts of beech, fir-beech and oak forests. Sampling sites were selected so as to include different types of spruce stands with regard to soil properties, climate and stand age (over 30 years). According to Koppen's climatic classification (Šegota \& Filipčić 2003) the study area shows a temperature humid climate with hot summer ( $\mathrm{Cfb}$ ). The climate data were provided by the Croatian Meteorological and Hydrological Service from meterological stations that are the nearest to the investigated sites (Tab. 1). Natural stands at sites Ivanec, Lepoglava, Sošice i Žumberak belong to the beech forest with dead nettle (Lamio orvalae-fagetum /Horvat 1938/ Borhidi 1963), Medvednica and Macelj sites to the beech-fir forests (Festuco drymeiae-Abietum Vukelić et Baričević 2007) and sites Bosiljevo and Jalžabet forest to the sessile oak and common hornbeam (Epimedio-Carpinetum betuli /Horvat 1938/ Borhidi 1963). On the site Jalžabet, a degradation stage of sessile oak forest with bracken fern (Pteridium aquilinum) as dominant species was found. The specific information about study sites is given in Tab. 1.

\section{Soil sample collection and analysis}

At each selected locality, composite soil samples were collected both at a plot with- in the spruce plantation and in one nearby plot covered by natural vegetation (natural stand) located in close proximity of the plantation (Fig. 1, Tab. 1). Five composite samples of forest floor were also taken at each plot to calculate the forest floor load $\left(\mathrm{Mg} \mathrm{ha}^{-1}\right)$. Each composite forest floor sample consisted of three subsamples taken within a frame of $25 \times 25 \mathrm{~cm}$, and the total fresh weight was measured considering all layers taken together (L, $\mathrm{F}$ and $\mathrm{H}$ horizons). The composite soil samples from the depths $0-10 \mathrm{~cm}$ and $10-20 \mathrm{~cm}$ were taken using an $80 \mathrm{~mm}$ diameter plastic probe and consisted of five subsamples taken at intervals of $1 \mathrm{~m}$ in a cross-shaped distribution. At each locality, five composite samples were taken from each layer, both in the spruce plantation and in the natural stand (20 samples per locality, totalling 160 samples). In each spruce plantation, a pedological profile was opened for the purpose of describing the endo-morphological properties of the soil. The following parameters were determined: share of soil skeleton by genesis horizons, thickness of horizons and total depth of the profile (FAO 2006). For

Tab. 1 - Basic characteristics of the study sites. The second row of each site represent the natural vegetation (reference plots).

\begin{tabular}{|c|c|c|c|c|c|c|c|c|c|c|c|}
\hline Site & $\begin{array}{l}\text { Vegetation } \\
\text { type }\end{array}$ & $\begin{array}{l}\text { Long } \mathrm{E} \\
\text { Lat } \mathrm{N}\end{array}$ & 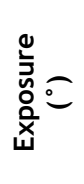 & 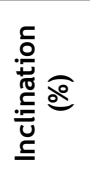 & 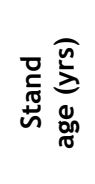 & 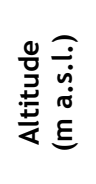 & 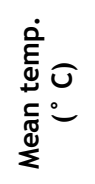 & 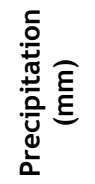 & $\begin{array}{l}\text { Parent } \\
\text { material }\end{array}$ & $\begin{array}{l}\text { Soil type } \\
\text { (WRB) }\end{array}$ & $\begin{array}{l}\text { Soil } \\
\text { texture }\end{array}$ \\
\hline \multirow{2}{*}{ Bosiljevo } & Spruce culture & $\begin{array}{l}15^{\circ} 18^{\prime} 19^{\prime \prime} \mathrm{E} \\
45^{\circ} 24^{\prime} 50^{\prime \prime} \mathrm{N}\end{array}$ & 310 & 5 & 41 & \multirow{2}{*}{212} & \multirow{2}{*}{10.9} & \multirow{2}{*}{1095} & \multirow{2}{*}{$\begin{array}{l}\text { Loess } \\
\text { sediment on } \\
\text { fossil red soil }\end{array}$} & \multirow{2}{*}{$\begin{array}{l}\text { Haplic } \\
\text { Cambisol } \\
\text { (Dystric) }\end{array}$} & \multirow{2}{*}{ Silt loam } \\
\hline & Sessile oak & $\begin{array}{l}15^{\circ} 18^{\prime} 16^{\prime \prime} \mathrm{E} \\
45^{\circ} 24^{\prime} 50^{\prime \prime} \mathrm{N}\end{array}$ & 300 & 7 & 41 & & & & & & \\
\hline \multirow{2}{*}{ Ivanec } & Spruce culture & $\begin{array}{l}16^{\circ} 07^{\prime} 07^{\prime \prime} \mathrm{E} \\
46^{\circ} 12^{\prime} 03^{\prime \prime} \mathrm{N}\end{array}$ & 10 & 26 & 36 & \multirow{2}{*}{423} & \multirow{2}{*}{10.2} & \multirow{2}{*}{1050} & \multirow{2}{*}{$\begin{array}{l}\text { Dolomitized } \\
\text { limestome }\end{array}$} & \multirow{2}{*}{ Leptic Calcisol } & \multirow{2}{*}{$\begin{array}{l}\text { Silt clay } \\
\text { loam }\end{array}$} \\
\hline & $\begin{array}{l}\text { Montane beech } \\
\text { forest }\end{array}$ & $\begin{array}{l}16^{\circ} 07^{\prime} 13^{\prime \prime} \mathrm{E} \\
46^{\circ} 12^{\prime} 01^{\prime \prime} \mathrm{N}\end{array}$ & 0 & 29 & 80 & & & & & & \\
\hline \multirow{2}{*}{ Jalžabet } & Spruce culture & $\begin{array}{l}16^{\circ} 26^{\prime} 38^{\prime \prime} \mathrm{E} \\
46^{\circ} 14^{\prime} 29^{\prime \prime} \mathrm{N}\end{array}$ & 270 & 15 & 30 & \multirow{2}{*}{230} & \multirow{2}{*}{10.8} & \multirow{2}{*}{820} & \multirow{2}{*}{$\begin{array}{l}\text { Loess } \\
\text { sediment }\end{array}$} & \multirow{2}{*}{$\begin{array}{l}\text { Haplic } \\
\text { Cambisol } \\
\text { (Dystric) }\end{array}$} & \multirow{2}{*}{ Silt loam } \\
\hline & Sessile oak & $\begin{array}{l}16^{\circ} 26^{\prime} 39^{\prime \prime} \mathrm{E} \\
46^{\circ} 14^{\prime} 31^{\prime \prime} \mathrm{N}\end{array}$ & 270 & 5 & 30 & & & & & & \\
\hline \multirow{2}{*}{ Lepoglava } & Spruce culture & $\begin{array}{l}16^{\circ} 02^{\prime} 12^{\prime \prime} \mathrm{E} \\
46^{\circ} 16^{\prime} 12^{\prime \prime} \mathrm{N}\end{array}$ & 20 & 24 & 30 & \multirow{2}{*}{260} & \multirow{2}{*}{10.2} & \multirow{2}{*}{1050} & \multirow{2}{*}{ Limestone } & \multirow{2}{*}{$\begin{array}{l}\text { Leptic } \\
\text { Cambisol } \\
\text { (Dystric) }\end{array}$} & \multirow{2}{*}{$\begin{array}{l}\text { Silt clay } \\
\text { loam }\end{array}$} \\
\hline & $\begin{array}{l}\text { Montane beech } \\
\text { forest }\end{array}$ & $\begin{array}{l}16^{\circ} 01^{\prime} 53^{\prime \prime} \mathrm{E} \\
46^{\circ} 16^{\prime} 49^{\prime \prime} \mathrm{N}\end{array}$ & 20 & 25 & 80 & & & & & & \\
\hline \multirow{2}{*}{ Macelj } & Spruce culture & $\begin{array}{l}15^{\circ} 49^{\prime} 15^{\prime \prime} \mathrm{E} \\
46^{\circ} 14^{\prime} 54^{\prime \prime} \mathrm{N}\end{array}$ & 195 & 27 & 44 & \multirow{2}{*}{330} & \multirow{2}{*}{9.3} & \multirow{2}{*}{1196} & \multirow{2}{*}{ Sandstone } & \multirow{2}{*}{$\begin{array}{l}\text { Haplic } \\
\text { Cambisol } \\
\text { (Dystric) }\end{array}$} & \multirow{2}{*}{ Sand loam } \\
\hline & Beech-fir forest & $\begin{array}{l}15^{\circ} 49^{\prime} 23^{\prime \prime} \mathrm{E} \\
46^{\circ} 14^{\prime} 47^{\prime \prime} \mathrm{N}\end{array}$ & 190 & 32 & 80 & & & & & & \\
\hline & Spruce culture & $\begin{array}{l}15^{\circ} 58^{\prime} 51^{\prime \prime} \mathrm{E} \\
45^{\circ} 55^{\prime} 03^{\prime \prime} \mathrm{N}\end{array}$ & 20 & 26 & 85 & 765 & 71 & 1252 & Grooncrbict & Haplic & loam \\
\hline Meaveanica & Beech-fir forest & $\begin{array}{l}15^{\circ} 58^{\prime} 58^{\prime \prime} \mathrm{E} \\
45^{\circ} 55^{\prime} 08^{\prime \prime} \mathrm{N}\end{array}$ & 20 & 28 & 100 & 105 & 1.1 & $1 \angle 3 \angle$ & Greenscnist & (Dystric) & Loam \\
\hline Sošice & Spruce culture & $\begin{array}{l}15^{\circ} 23^{\prime} 15^{\prime \prime} \mathrm{E} \\
45^{\circ} 44^{\prime} 08^{\prime \prime} \mathrm{N}\end{array}$ & 65 & 24 & 38 & 765 & 109 & 1079 & limestone & Leptic & \\
\hline Jusile & $\begin{array}{l}\text { Montane beech } \\
\text { forest }\end{array}$ & $\begin{array}{l}15^{\circ} 23^{\prime} 17^{\prime \prime} \mathrm{E} \\
45^{\circ} 44^{\prime} 04^{\prime \prime} \mathrm{N}\end{array}$ & 65 & 24 & 28 & 160 & 10.9 & $10 / 9$ & Limestone & $\begin{array}{l}\text { Cambisol } \\
\text { (Dystric) }\end{array}$ & silt loam \\
\hline & Spruce culture & $\begin{array}{l}15^{\circ} 28^{\prime} 38^{\prime \prime} \mathrm{E} \\
45^{\circ} 46^{\prime} 58^{\prime \prime} \mathrm{N}\end{array}$ & 220 & 13 & 55 & & & & & Haplic & Silt clay \\
\hline Zumberak & $\begin{array}{l}\text { Montane beech } \\
\text { forest }\end{array}$ & $\begin{array}{l}15^{\circ} 28^{\prime} 37^{\prime \prime} \mathrm{E} \\
45^{\circ} 46^{\prime} 59^{\prime \prime} \mathrm{N}\end{array}$ & 220 & 15 & 105 & 720 & 10.9 & 1079 & Marl & $\begin{array}{l}\text { Cambisol } \\
\text { (Dystric) }\end{array}$ & loam \\
\hline
\end{tabular}


laboratory analyses, air-dried soil samples were used. Samples were crumbled and sieved twice ( 2 and $0.2 \mathrm{~mm}$ mesh - ISO11464 1994). The following pedo-physiographic parameters were measured for each sample: particle size distribution (ISO11277 2009), $\mathrm{pH}$ value of soil in $\mathrm{H}_{2} \mathrm{O}$ and in $\mathrm{CaCl}_{2}$ aqueous solution (concentration 0.01 mol dm ${ }^{-3}$ - ISO-10390 2005), carbonate content - volumetric method (ISO-10693 1995), carbon content ( $C_{\text {tot }}-$ ISO-10694 1995) and nitrogen content ( $\mathrm{N}_{\text {tot }}-$ ISO-13878 1998) using the Flash $2000^{\circledR}$ Combustion NC Soil Analyzer (Thermo Fisher Scientific, Waltham, MA, USA). The forest flooor samples were sieved through $2 \mathrm{~mm}$ sieve in laboratory and the minerals were extracted from organic soil. Forest floor samples were dried at a temperature of $50{ }^{\circ} \mathrm{C}$ (Pernar et al. 2013) until constant mass was reached and used to determine the forest floor load per unit area. The share of bioavailable elements ( $\mathrm{P}, \mathrm{K}, \mathrm{Ca}, \mathrm{Mg}$ and $\mathrm{Fe}$ ) following extraction by Mehlich III solution was determined using atomic emission spectrometry with inductively coupled plasma ICP-AES (Mehlich 1984).

For all the analysed variables, detailed descriptive analysis was obtained for each site. The differences between plantations and natural stands were tested using the $t$ test when the condition of homogeneity of variance was met; otherwise, the non-parametric Mann-Whitney U-test was used. All statistical analysis was performed using the software package Statistica ${ }^{\oplus}$ ver. 8.0 (StatSoft Inc., Tulsa, OK, USA).

\section{Results and discussion}

\section{Forest floor}

The analysis of data by site revealed that there was a greater accumulation of the forest floor layer (L, F and $\mathrm{H}$ - together) in spruce plantations in comparison to natural stands, with the exception of the site Ivanec (Fig. 2). The greater mass of forest floor in natural stands at Ivanec compared to the corresponding plantation could be due to the site aspect (north-facing), which results in a slower decomposition of organic matter, and the age of the natural stands. Many studies reported a larger accumulation of forest floor load in spruce plantations in comparison with beech forests (Bagherzadeh et al. 2008, Fabiánek et al. 2009, Berger \& Berger 2012) or oak forests (Perković et al. 2007), which are the reference stands in this study. The reason of the greater accumulation of organic matter in spruce plantations is the slower decomposition of organic material (needles) due to the higher ratio of slowly decomposing organic compounds (Haider 1992, Gartner \& Cardon 2004, Berger \& Berger 2012). According to Kubartová et al. (2009), the rate of decomposition of organic remnants increases in the following order: common pine < spruce < Douglas fir $<$ beech. Furthermore, the higher accumulation of organic matter in spruce planta-

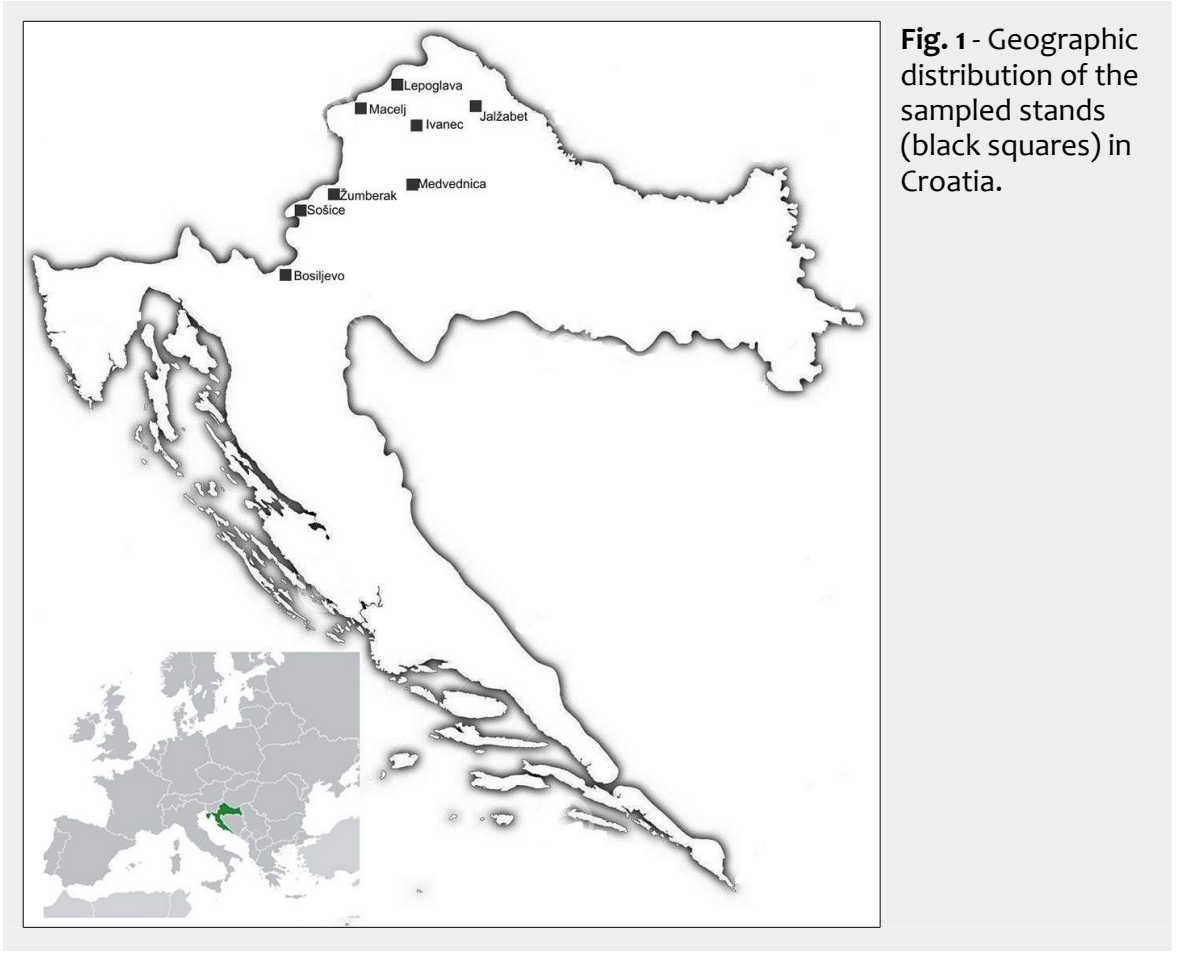

tions largely depends on other habitat properties, particularly climate and soil quality (Johnson \& Curtis 2001). Spruce plantations show a different microclimate compared to broadleaved forests, mainly due to the lower insolation of soil and the affecting the process of decomposition of organic matter. In this study, the average mass of the forest floor in spruce plantations was about $30 \%$ higher than in natural stands. The greatest difference was found at the site Bosiljevo, where the forest floor higher interception of precipitation, thus mass in the spruce plantation was three

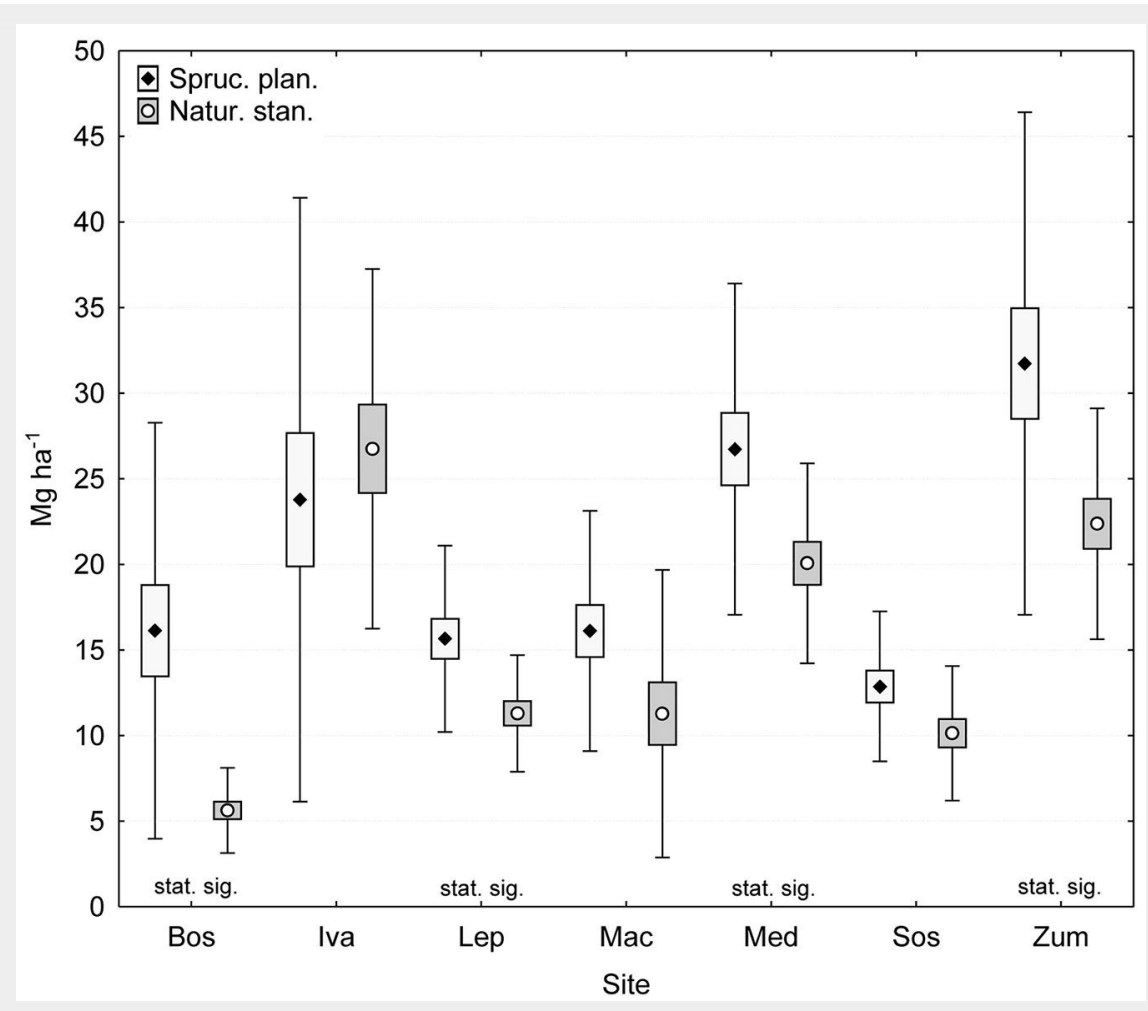

Fig. 2 - Results of the $t$-test or Mann-Whitney $U$ test on the differences in the accumulation of leaf litter between spruce plantations (Spruc. plan.) and natural stands (Natur. stan.) at each study site (Bos - Bosiljevo; Iva - Ivanec; Jal - Jalžabet; Mac Macelj; Med - Medvednica; Sos - Sošice; Zum - Žumberak):, (stat. sig.): statistically significant. 


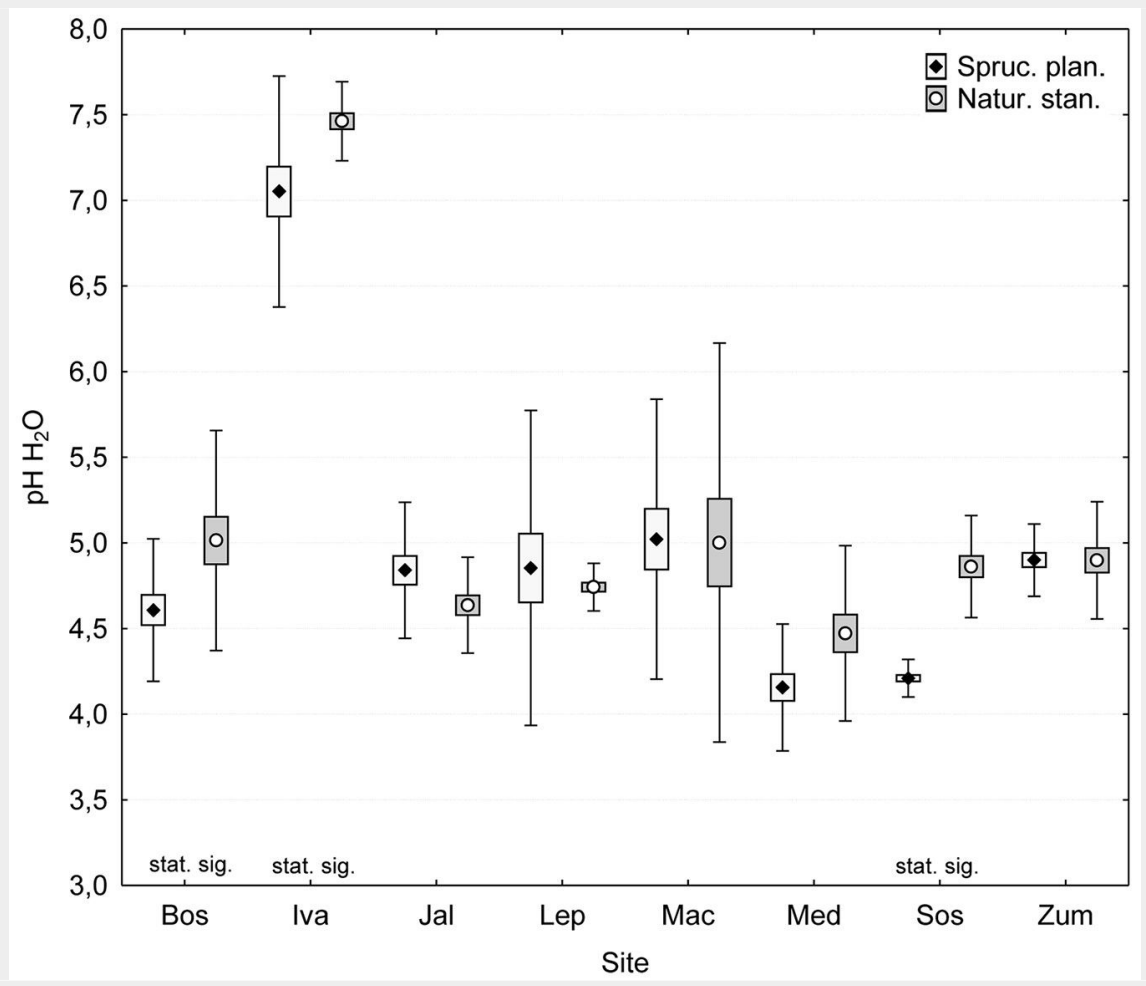

Fig. 3 - Soil $\mathrm{pH}_{\mathrm{H}_{2} \mathrm{O}}$ in the surface layer $(0-10 \mathrm{~cm})$. Differences were tested between spruce plantations (Spruc. plan.) and natural stands (Natur. stand) at the study sites (Bos - Bosiljevo; Iva - Ivanec; Jal - Jalžabet; Lep - Lepoglava; Mac - Macelj; Med Medvednica; Sos - Sošice; Zum - Žumberak); (stat. sig.): statistically significant.

times greater than in the corresponding natural stand. Considering the average value (arithmetic mean), the forest floor mass in spruce plantations ranged from $12.87 \mathrm{Mg} \mathrm{ha}^{-1}$ (Sošice) to $31.74 \mathrm{Mg} \mathrm{ha}^{-1}$ (Žumberak), as opposed to $5.63 \mathrm{Mg} \mathrm{ha}^{-1}$ (Bosiljevo) to $26.76 \mathrm{Mg} \mathrm{ha}^{-1}$ (Ivanec) in natural stands. According to Perković et al. (2007), the forest floor stock ranged from 17.5 to $31 \mathrm{Mg} \mathrm{ha}{ }^{-1}$ in 35-40 year old spruce plantations planted in pedunculate oak and hornbeam habitat, which was two to three times higher than in the natural stand. Klimo \& Kulhavy (2006) found a higher stock of forest floor (over $50 \mathrm{Mg} \mathrm{ha}^{-1}$ ) in spruce plantations within the range of beech forests than in beech stands in the Czech Republic, which could be attributed to the greater humidity of the study area. Statisti-

cally significant differences were found at the sites Žumberak, Medvednica, Lepoglava and Bosiljevo (Fig. 2), which confirms the findings reported elsewhere (Bagherzadeh et al. 2008, Perković et al. 2007).

\section{Soil properties}

In the surface soil layer $(0-10 \mathrm{~cm})$, the $\mathrm{pH}$ value was lower in the spruce plantations than in the natural stands. The same trends were found for both $\mathrm{pH}_{\mathrm{H} 20}$ and $\mathrm{pH}_{\mathrm{CaCl} 2}$. A slightly higher $\mathrm{pH}$ value in spruce plantations was found at the sites Jalžabet and Lepoglava, though the differences were not statistically significant (Fig. 3). Lower $\mathrm{pH}$ values in the surface layer of soil in spruce plantations were found at the sites Bosiljevo, Ivanec and Sošice (Tab. S1 in Supplementary material). The lowest $\mathrm{pH}$ value

Tab. 2 - Correlation coefficients bewteen the tested soil parameters. $\left({ }^{*}\right): p<0.05$.

\begin{tabular}{lllllllllll}
\hline- & $\mathrm{pH}_{\mathrm{H} 2 \mathrm{O}}$ & $\mathrm{pH}_{\mathrm{CaCl} 2}$ & $\mathrm{C}$ org & $\mathrm{N}$ tot & $\mathrm{C} / \mathrm{N}$ & $\mathrm{Ca}$ & $\mathrm{Fe}$ & $\mathrm{K}$ & $\mathrm{Mg}$ & $\mathrm{P}$ \\
\hline $\mathrm{pH}_{\mathrm{H} 2 \mathrm{O}}$ & 1.00 & - & - & - & - & - & - & - & - & - \\
$\mathrm{pH}_{\mathrm{CaCl} 2}$ & $0.97^{*}$ & 1.00 & - & - & - & - & - & - & - & - \\
$\mathrm{C}$ org & 0.10 & $0.17^{*}$ & 1.00 & - & - & - & - & - & - & - \\
$\mathrm{N}$ tot & $0.22^{*}$ & $0.30^{*}$ & $0.97^{*}$ & 1.00 & - & - & - & - & - & - \\
$\mathrm{C} / \mathrm{N}$ & $-0.23^{*}$ & $-0.29^{*}$ & -0.04 & $-0.21^{*}$ & 1.00 & - & - & - & - & - \\
$\mathrm{Ca}$ & $0.89^{*}$ & $0.91^{*}$ & $0.30^{*}$ & $0.41^{*}$ & $-0.31^{*}$ & 1.00 & - & - & - & - \\
$\mathrm{Fe}$ & $-0.51^{*}$ & $-0.49^{*}$ & $0.31^{*}$ & $0.22^{*}$ & 0.14 & $-0.44^{*}$ & 1.00 & - & - & - \\
$\mathrm{K}$ & -0.14 & -0.08 & $0.40^{*}$ & $0.38^{*}$ & $-0.16^{*}$ & -0.01 & $0.51^{*}$ & 1.00 & - & - \\
$\mathrm{Mg}$ & $0.87^{*}$ & $0.89^{*}$ & $0.26^{*}$ & $0.36^{*}$ & $-0.27^{*}$ & $0.86^{*}$ & $-0.34^{*}$ & 0.08 & 1.00 & - \\
$\mathrm{P}$ & $-0.19^{*}$ & -0.14 & $0.26^{*}$ & $0.23^{*}$ & 0.03 & -0.07 & $0.40^{*}$ & $0.41^{*}$ & -0.06 & 1.00 \\
\hline
\end{tabular}

in spruce plantations was found in the district cambisol over green slate rock at the site Medvednica $\left(\mathrm{pH}_{\mathrm{H} 20} 4.16 \pm 0.19 ; \mathrm{pH}_{\mathrm{CaCl} 2}\right.$ $3.39 \pm 0.11$ ), while the highest $\mathrm{pH}$ value was found over dolomitised limestone at the site Ivanec $\left(\mathrm{pH}_{\mathrm{H} 2 \mathrm{O}} 7.05 \pm 0.34 ; \mathrm{pH}_{\mathrm{CaCl}_{2}} 6.45 \pm\right.$ 0.40 - Fig. 2, Tab. 1). Previous reports indicated that Norway spruce contributes to increase the soil acidity (Hagen-Thorn et al. 2004, Berger \& Berger 2012, Kostić et al. 2012), which is largely confirmed by the findings of this study. Stand age has also been proven to affect soil $\mathrm{pH}$ in spruce plantations. Cerli et al. (2006), Podrázsky \& Remeš (2007) and Smal \& Olszewska (2008) pointed out the influence of stand age on soil acidification, with lower $\mathrm{pH}$ values in soil of older stands in comparison to younger spruce plantations. Accordingly, the reason for the slightly higher $\mathrm{pH}$ values of soil in spruce plantations at the sites Jalžabet and Lepoglava could be attributed to the relatively young age of those plantations. Furthermore, the Jalžabet control plot also includes eastern bracken fern (Pteridium aquilinum), a species that also promote soil acidification (Wood 1995, Johnson-Maynard et al. 1998).

In the deeper soil layer $(10-20 \mathrm{~cm})$, statistically significantly lower $\mathrm{pH}$ values in spruce plantations were found at the sites Bosiljevo and Sošice, while at all other sites $\mathrm{pH}$ was lower but not significantly different, with the exception of the site Lepoglava where $\mathrm{pH}$ values were higher than in the natural stands (Tab. S1 in Supplementary material).

Organic carbon content in the surface soil layer $(0-10 \mathrm{~cm})$ were higher in natural stands, with the exception of the sites Lepoglava and Sošice, though differences were statistically significant only at the sites Macelj, Jalžabet and Ivanec (Tab. S1). The results obtained in this study differ from those in Vesterdal et al. (2008), who reported that reforestation with coniferous species results in increasing organic carbon stocks in the soil. In the deeper soil layer $(10-20 \mathrm{~cm})$, organic carbon content was lower than in the surface layer, while the relationship between the spruce plantations and natural stands by site was similar to that observed in the surface layer (Tab. 2). The highest organic carbon content in the surface layer $(0-10 \mathrm{~cm})$ was found at the sites Medvednica (SP: $116.1 \mathrm{~g}$ $\mathrm{kg}^{-1}$; N: $115.4 \mathrm{~g} \mathrm{~kg}^{-1}$ ) and Ivanec (SP: $54.8 \mathrm{~g}$ $\mathrm{kg}^{-1} ; \mathrm{N}: 114.9 \mathrm{~g} \mathrm{~kg}^{-1}$ ), where the largest accumulation of forest floor was also found (Fig. 2, see also Tab. S1 in Supplementary material).

The nitrogen content showed an identical pattern as the total carbon content at the study sites. As a rule, the nitrogen content in the surface layer was higher in the natural stands, with the exception of the sites Lepoglava and Sošice. A number of studies (Meiwes et al. 2002, Bagherzadeh et al. 2008, Kostić et al. 2012) reported that beech litter has higher nitrogen content than spruce litter, determining a more 
favourable $\mathrm{C} / \mathrm{N}$ ratio in the soil. A higher nitrogen content generally suggests higher quality leaf litter and faster humus produc tion. The highest nitrogen content in the surface soil layer was found at Medvednica (SP: $7.7 \mathrm{~g} \mathrm{~kg}^{-1}$; N: $8.7 \mathrm{~g} \mathrm{~kg}^{-1}$ ) and Ivanec (SP: $10.3 \mathrm{~g} \mathrm{~kg}^{-1} ; \mathrm{N}: 3.9 \mathrm{~g} \mathrm{~kg}^{-1}$ ). The nitrogen content and $\mathrm{C} / \mathrm{N}$ ratio in the forest soil are important parameters for determining the influence of different tree species on the functioning of forest ecosystems (Vesterdal et al. 2008). The $\mathrm{C} / \mathrm{N}$ ratio is a very good indicator of the quality of organic matter in the soil (Batjes 1996), and a ratio higher than 25 reflects slower decomposition processes (Swift et al. 1979). When $\mathrm{C} / \mathrm{N}<30$, the decomposition of the leaf litter typically takes a year, while for higher $\mathrm{C} / \mathrm{N}$ values (50-70), decomposition may last from 3 to 40 years, and the lacking nitrogen is taken up from the soil. Numerous studies have found a higher $\mathrm{C} / \mathrm{N}$ ratio in spruce plantations in relation to oak forest (Perković et al. 2007) or beech forest (Bagherzadeh et al. 2008, Vesterdal et al. 2008, Prietzel \& Bachmann 2011, Berger \& Berger 2012). This is corroborated by the findings presented here, where the $\mathrm{C} / \mathrm{N}$ ratio was higher in spruce plantations, with the exception of two sites (Sošice and Žumberak), where the highest variability of this parameter was seen in the natural stands (Tab. S1). The $\mathrm{C} / \mathrm{N}$ ratio in the soil surface layer in spruce plantations was in the range from 13.9 to 15.4 , as opposed to 11.1 to 19.7 in natural stands. With increas ing depth, the $\mathrm{C} / \mathrm{N}$ ratio is reduced (Kostić et al. 2016). In the present study, the $\mathrm{C} / \mathrm{N}$ ratio at depths of $10-20 \mathrm{~cm}$ in the spruce plantations ranged from 11.1 to 14.9 , as opposed to 9.8 to 17.5 in natural stands. These results indicate the lesser variability of the $\mathrm{C} / \mathrm{N}$ ratio in the soil of spruce plantations in comparison to natural stands. Hypothetically, an increase in the $\mathrm{C} / \mathrm{N}$ ratio will result in slower decomposition, the accumulation of organic matter and a greater carbon sink in spruce stands. However, it should be noted that at all study sites, both spruce plantations and natural stands, a $\mathrm{C} / \mathrm{N}$ ratio of less than 20 was observed, indicating a favourable and rapid decomposition of the forest floor.

The bioavailable phosphorus in the surface soil layer $(0-10 \mathrm{~cm})$ in spruce plantations ranged from $5.42 \mathrm{mg} \mathrm{kg}^{-1}$ (Bosiljevo) to $46.91 \mathrm{mg} \mathrm{kg}^{-1}$ (Jalžabet). In the natural stands, the variability was lower, ranging from $7.60 \mathrm{mg} \mathrm{kg}^{-1}$ (Sošice) to $19.88 \mathrm{mg} \mathrm{kg}^{-1}$ (Macelj). The site Jalžabet had two to three times larger concentration of phos phorus in the spruce plantations than in natural stands (Tab. S1 in Supplementary material). Prudhomme et al. (2017) reported that phosphorus concentration in spruce plantations following extraction with Mehlich III solution ranges from 9.12 to $12.10 \mathrm{mg} \mathrm{kg}^{-1}$. At the sites Bosiljevo, Ivanec and Macelj, a higher phosphorous content was found in the natural stands, while at other sites the content was higher in spruce plantations. Bagherzadeh et al. (2008) and Kostić et al. (2012) reported higher average phosphorus concentrations in beech forest than in spruce plantations. On the other hand, Hansen et al. (2009) stated that beech litter has a higher share of all macronutrients except phosphorus than spruce litter. With increasing of the depth, the phosphorus content is reduced at all sites, which agrees with the results by Pernar et al. (2009), who stated that the phosphorus content is generally higher in the humus-accumulation horizon. The concentration of bioavailable phosphorus in the soil layer at $10-20 \mathrm{~cm}$ ranged from 3.64 $\mathrm{mg} \mathrm{kg}^{-1}$ (Ivanec) to $29.29 \mathrm{mg} \mathrm{kg}^{-1}$ (Jalžabet) in spruce plantations, and from $1.62 \mathrm{mg} \mathrm{kg}^{-1}$ (Žumberak) to $15.26 \mathrm{mg} \mathrm{kg}^{-1}$ (Macelj) in natural stands. In the deeper soil layer, the phosphorus content was generally higher (though not significantly) in spruce stands, with the exception of the site Ivanec (Tab. S1).

The concentration of bioavailable potassium in the surface soil layer $(0-10 \mathrm{~cm})$ in spruce plantations ranged from $27.90 \mathrm{mg}$ $\mathrm{kg}^{-1}$ (Žumberak) to $137.69 \mathrm{mg} \mathrm{kg}^{-1}$ (Medvednica), as opposed to the range of $33.77 \mathrm{mg}$ $\mathrm{kg}^{-1}$ (Žumberak) to $120.47 \mathrm{mg} \mathrm{kg}^{-1}$ (Bosiljevo) in natural stands. The potassium content was higher in natural stands, with the exception of the sites Ivanec, Jalžabet and Medvedica (Tab. S1 in Supplementary material). A lower potassium content in spruce plantations than in beech stands was also confirmed by Bagherzadeh et al. (2008). In the deeper soil layer, the potassium content was lower. As in the case of phosphorus, this is attributed to the accumulative effect of vegetation in the surface layer of the soil, while this is less common for calcium and magnesium (Vanmechelen et al. 1997). In deeper soil layers, the potassium content is generally higher in spruce plantations, with the exception of the sites Ivanec and Jalžabet. The concentration of bioavailable potassium in the soil layer 10$20 \mathrm{~cm}$ ranged from $21.60 \mathrm{mg} \mathrm{kg}^{-1}$ (Žumberak) to $72.42 \mathrm{mg} \mathrm{kg}^{-1}$ (Medvednica) in spruce plantations, and from $20.03 \mathrm{mg} \mathrm{kg}^{-1}$ (Žumberak) to $93.49 \mathrm{mg} \mathrm{kg}^{-1}$ (Medvednica) in natural stands. Higher variability in the potassium ratio was found at all localities in the natural stands (Tab. S1 in Supplementary material).

The bioavailable calcium did not show clear differences between natural stands and spruce plantations. Similar results were also reported by Podrázsky et al. (2018), who examined the differences between common fir stands and spruce plantations. A statistically higher share of calcium in the surface soil layer in natural stands was found at the sites Sošice and Ivanec, higher share at the sites Bosiljevo and Medvednica, while at all other sites, the ratio was higher in the spruce plantation (Tab. S1). In particular, the Ivanec site, lying on dolomitised limestone, stands out due to the many-fold higher concentrations of calcium than at the other sites (SP
$>2000 \mathrm{mg} \mathrm{kg}^{-1} ; \mathrm{N}>2000 \mathrm{mg} \mathrm{kg}^{-1}$ - Tab. S1). For all the localities examined in this study, a statistically significant positive correlation was found between soil $\mathrm{pH}$ and bioavailable calcium concentration $(r=0.89$ $0.91, p<0.05$ - Tab. 2).

The bioavailable magnesium was generally higher in natural stands than in spruce plantations. The higher values of bioavailable magnesium in spruce plantations in the surface layer was found at the sites Medvednica and Žumberak, while in the deeper layer, this was higher only at Žumberak. The highest value of bioavailable magnesium was found at the site Ivanec (> $500 \mathrm{mg} \mathrm{kg}^{-1}$ ), while the lowest was found at the site Sošice $\left(<50 \mathrm{mg} \mathrm{kg}^{-1}-\mathrm{Tab} . \mathrm{S} 1\right)$. The observed pattern for mobile magnesium across different sites was similar to that observed for calcium; indeed, a positive correlation was found between these elements $(r=0.86, p<0.05)$, as well as between $\mathrm{pH}$ and magnesium $(r=0.87-0.89$, p $<0.05$ - Tab. 2).

The content of bioavailable iron at the study sites showed no clear patterns between the spruce plantations and natural stands. On carbonate substrates (Ivanec, Lepoglava and Sošice) the concentration values of iron in the surface soil layer were higher then in spruce plantations, while at the remaining sites the concentration values were higher in natural stands, though not statistically significant (Tab. S1). The lowest values of iron concentration were found at the site Ivanec, where the concentration of calcium was highest, which is not surprising given the carbonate substrate. $\mathrm{A}$ negative correlation was found between the content of bioavailable iron and calcium $(r=-0.46, p<0.05-$ Tab. 2$)$. The reason for the lower concentration values of iron observed in soils with carbonate substrate is the formation of less soluble iron carbonates (Lindsay \& Schwab 2008).

In summary, we found no clear and characteristic relationship between the concentration values of bioavailable fraction of elements between the spruce plantations and natural stands. This can largely be attributed to the properties of the leaf litter of spruce, beech and fir, which were the main species in this study. Bergmann (1988) stated that the concentrations of these bioelements are virtually identical among the leaves of beech and needles of fir and spruce trees.

This study showed that spruce plantations affect soil $\mathrm{pH}$, forest floor mass and $\mathrm{C} / \mathrm{N}$ ratio, while the differences observed for the other parameters cannot be clearly attributed to spruce plantations. Other factors, such as the different plantation age (Tab. 1) as well as different lithological and bioclimatic conditions among plot pairs and sites, could mask further differences thus hindering the interpretation of the results. However, the objective of this study was to determine recognizable and easily observable influences of Norway spruce plantations on forest soil, which stand out 
despite the diverse conditions that are typical in this part of Europe. On the other hand, several studies suggested that in addition to tree species, the substrate and micro- and macroclimate can also have a substantial effect on the chemical parameters of soil (Augusto et al. 2002, Hagen-Thorn et al. 2004).

\section{Conclusions}

The objective of this study was to analyse the effect of spruce plantations of different age grown on different soils under various climatic conditions on soil characteristics, and compare them to those found in close natural stands. The results showed a clear influence of spruce plantations on several soil parameters. The mass of the forest floor was on average $30 \%$ higher in spruce plantations than in the surrounding natural stands. A lower soil pH was also observed, indicating the soil acidification which occurs in Norway spruce plantations. At most sites, the soil in spruce plantations had a lower nitrogen content and, as a consequence, a higher $\mathrm{C} / \mathrm{N}$ ratio, indicating poor quality organic matter. Further, the content of bioavailable phosphorous was lower in plantations than in natural stands, while no differences were determined for the other tested elements (potassium, calcium, magnesium and iron). Our results allow drawing the main conclusion that spruce plantations have an unfavourable influence on soil in comparison to the natural vegetation.

\section{Acknowledgements}

This research was supported by Fund for the development of the University of Zagreb (project: Influence of Norway spruce [Picea abies L., H. Karst] stands on soil).

\section{References}

Augusto L, Ranger J, Binkley D, Rothe A (2002). Impact of several common tree species of European temperate forests on soil fertility. Annals of Forest Science 59: 233-253. - doi: 10.1051/ forest:2002020

Bagherzadeh A, Brumme R, Beese F (2008). Impact of tree species on nutrient stocks in the forest floors of a temperature forest ecosystem. Pakistan Journal of Biological Sciences 11 (9): 1258-1262. - doi: 10.3923/pjbs.2008.1258.12 62

Batjes NH (1996). Total carbon and nitrogen in the soils of the world. European Journal of Soil Science 47: 151-163. - doi: 10.1111/j.1365-2389.199 6.tb01386.x

Berger TW, Berger P (2012). Greater accumulation of litter in spruce (Picea abies) compared to beech (Fagus sylvatica) stands is not a consequence of the inherent recalcitrance of needles. Plant and Soil 385: 349-369. - doi: 10.1007/ s11104-012-1165-z

Berger TW, Köllensperger G, Wimmer R (2004). Plant-soil feedback in spruce (Picea abies) and mixed spruce-beech (Fagus sylvatica) stands as indicated by dendrochemistry. Plant and Soil 264: 69-83. - doi: 10.1023/B:PLSO.0000047714.4 3253.25
Berg B, McClaugherty C (2008). Plant litter: decomposition, humus formation, carbon sequestration. In: "Climatic Environment" ( $\left.2^{\text {nd }} e d n\right)$. Springer, Berlin Heidelberg, Germany, pp. 143170.

Bergmann W (1988). Ernährungsstörungen bei Kulturpflanzen: Entstehung, visuelle und analytische Diagnose [Nutritional disorders in crops: development, visual and analytical diagnosis]. Gustav Fisher Verlag, Jena, Germany, pp. 381. [in German]

Binkley D, Valentine D (1991). Fifty-year biogeochemical effects of green ash, white pine, and Norway spruce in a replicated experiment. Forest Ecology and Management 40: 13-25. - doi: 10.1016/0378-1127(91)90088-D

Cerli CH, Celi L, Johansson MB, Kögel-Knabner I, Rosenqvist L, Zanini E (2006). Soil organic matter changes in a spruce chronosequence on Swedish former agricultural soil. I. Carbon and lignin dynamics. Soil Science 171 (11): 837-849. doi: 10.1097/01.5s.0000228061.23334.98

Fabiánek T, Menšík L, Tomášková I, Kulhavý J (2009). Effects of spruce, beech and mixed commercial stand on humus conditions of forest soils. Journal of Forest Science 55 (3): 119126. - doi: 10.17221/70/2008-JFS

FAO (2006). Guidelines for soil description ( $4^{\text {th }}$ edn). Food and Agriculture Organization of the United Nation, Rome, Italy, pp. 21-32.

Galvan P, Ponge JF, Chersich S, Zanella A (2008). Humus components and soil biogenic structures in Norway spruce ecosystems. Soil Science Society of America Journal 72 (2): 548-557. doi: 10.2136/sssaj2006.0317

Gartner TB, Cardon ZG (2004). Decomposition dynamics in mixed-species leaf litter. Oikos 104: 230-246. - doi: 10.1111/j.0030-1299.2004.12738.x

Hagen-Thorn A, Callesen I, Armolaitis K, Nihlgård $B$ (2004). The impact of six European tree species on the chemistry of mineral topsoil in forest plantation on former agricultural land. Forest Ecology and Management 195: 373-384. doi: 10.1016/j.foreco.2004.02.036

Haider K (1992). Problems related to the humification processes in soils of the temperate climate. In: "Soil Biochemistry 7" (Bollag JM, Strotzky G eds). M. Dekker, New York, USA, pp. 55-94. [online] URL: http://books.google.com/ books?id=ZgDSu602 $\mathrm{CW}_{4} \mathrm{C}$

Hansen K, Vesterdal L, Schmidt IK, Gundersen P, Sevel L, Bastrup-Birk A, Pedersen LB, BilleHansen J (2009). Litterfall and nutrient return in five tree species in a common garden experiment. Forest Ecology and Management 257: 2133-2144. - doi: 10.1016/j.foreco.2009.02.021

ISO-10390 (2005). Soil quality - Determination of pH. ISO, Genève, Switzerland, pp. 1-7.

ISO-10693 (1995). Soil quality - Determination of carbonate content - Volumetric method. ISO, Genève, Switzerland, pp 1-7.

ISO-10694 (1995). Soil quality - Determination of organic and total carbon after dry combustion (elementary analysis). ISO, Genève, Switzerland, pp 1-7.

ISO-11277 (2009). Soil quality - Determination of particle size distribution in mineral soil material - Method by sieving and sedimentation. ISO, Genève, Switzerland, pp. 1-34.

ISO-11464 (1994). Soil quality - Pretreatment of samples for physico-chemical analyses. ISO,
Genève, Switzerland, pp. 1-11.

ISO-13878 (1998). Soil quality - Determination of total nitrogen content by dry combustion (elemental analysis). ISO, Genève, Switzerland, pp. 1-5.

Johnson DW, Curtis PS (2001). Effects of forest management on soil $\mathrm{C}$ and $\mathrm{N}$ storage: meta analysis. Forest Ecology and Management 140: 227-238. - doi: 10.1016/S0378-1127(00)00282-6

Johnson-Maynard JL, MCDaniel PA, Ferguson DE, Falen AL (1998). Changes in soil solution chemistry of andisols following invasion by Bracken fern. Soil Science 163 (10): 814-821. - doi: 10.109 7/00010694-199810000-00005

Klimo E (2000). Stress factors in the ecosystems of Norway spruce monocultures, induced by changed soil properties and nutrient cycling. Ekologia 19 (1): 113-129.

Klimo E, Kulhavy J (2006). Norway spruce monocultures and their transformation to close-tonature forests from the point of view of soil changes in the Czech Republic. Ekológia 25 (1): 27-43. [online] URL: http://147.213.211.222/sites/ default/files/ek10604_klimo.pdf

Kostić O, Mitrović M, Jarić S, Djurdjević L, Gajić G, Pavlović M, Pavlović P (2012). The effects of forty years of spruce cultivation in a zone of beech forest on Mt. Maljen (Serbia). Archives of Biological Sciences 64 (3): 1181-1195. - doi: 10.2298/ABS1203181K

Kostić O, Jarić S, Gajić G, Pavlović D, Marković M, Mitrović M, Pavlović P (2016). The effects of Douglas Fir monoculture on stand characteristics in a zone of Montane beech forest. Archives of Biological Sciences 68 (00): 753-766. doi: 10.2298/ABS150911032K

Kubartová A, Ranger J, Berthelin J, Beguiristain T (2009). Diversity and decomposing ability of saprophytic fungi from temperate forest litter. Microbial Ecology 58 (1): 98-107. - doi: 10.1007/ s00248-008-9458-8

Lindsay WL, Schwab AP (2008). The chemistry of iron in soils and its availability to plants. Journal of Plant Nutrition 5 (1982): 821-840. - doi: 10.108 o/01904168209363012

Lesná J, Kulhavy J (2003). Evaluation of humus conditions under different forest stands: beech vs. spruce dominated forest stands. Ekológia 22 (3): 47-60.

Mareschal L, Bonnaud P, Turpault MP, Ranger J (2010). Impact of common European tree species on the chemical and physicochemical properties of fine earth: an unusual pattern. European Journal of Soil Science 61: 14-23. - doi: 10.1111/j.1365-2389.2009.01206.x

Mehlich A (1984). Mehlich-3 soil test extractant: a modification of Mehlich-2 extractant. Communications in Soil Science and Plant Analysis 15 (12): 1409-1416. - doi: 10.1080/0010362840936 7568

Meiwes KJ, Meesenburg H, Bartens H, Khanna PPA (2002). Akkumulation von Auflagehumus im Solling Mögliche Ursachen und Bedeutung für den Nährstoffkreislauf [Accumulation of humus in the litter layer of forest stands at Solling. Possible causes and significance for the nutrient cycling]. Aus Forst und Holz 57: 428433. [in German]

Moukoumi J, Munier-Lamy C, Berthelin J, Ranger $J$ (2006). Effect of tree species substitution on organic matter biodegradability and mineral 
nutrient availability in temperate topsoil. Annals of Forest Science 63: 763-771. - doi: 10.1051/ forest:2006057

Oršanić M, Vukelić J, Pernar N (2000). The possibility of converting spruce monocultures into autochthonous stands in Croatia. In: "Spruce Monocultures in Central Europe - Problems and Prospects" (Klimo E, Hager H, Kulhavý J eds). EFI Proceedings 33, pp. 189-197.

Penízek V, Zádorova T (2012). Soil toposequence under man-planted vegetation in the Krkonoše Mts., Czech Republic. Soil and Water Research 7 (4): 138-50. - doi: 10.17221/11/2012-SWR

Perić S, Orlić S, Dokuš A (2006). Pregled osnovanih pokusa provenijencija i kultura četinjača Šumarskog instituta, Jastrebarsko [An overview of established provenance test and conifer cultures of the Forest Reaserch Institute Jastrebasrsko]. Radovi Šumarskog instituta Jastrebarsko 41 (1-2): 115-126. [in Croatian]

Perković I, Pernar N, Vrbek B, Bakšić D, Pilaš I, Presečan M (2007). Utjecaj kulture obične smreke na tlo [The impact of Norway Spruce on soil]. Radovi Šumarskog instituta Jastrebarsko 42 (2): 95-108. [in Croatian]

Pernar N, Bakšić D, Perković I (2013). Terenska i laboratorijska istraživanja tla, priručnik za uzorkovanje i analizu [Soil survey field and laboratory methods, sampling and analysis methods]. Udžbenici Sveučilišta u Zagrebu, Šumarski fakultet Sveučilišta u Zagrebu, pp. 192. [in Croatian]

Pernar N, Vukelić J, Bakšić D, Baričević D, Perković I, Miko S, Vrbek B (2009). Soil properties in beech-fir forests on Mt. Medvednica (NW
Croatia). Periodicum Biologorum 111 (4): 427434. [online] URL: http://hrcak.srce.hr/index. php?show=clanak\&id_clanak_jezik=73905

Podrázsky V, Remeš J (2007). Changes of soil chemistry in the Norway spruce forest ecosystems of the middle altitudes. Scientia Agriculturae Bohemica 38 (1): 48-51. [online] URL: http://agris.fao.org/agris-search/search.do?reco rdID $=C Z 2007000321$

Podrázsky V, Vacek Z, Kupka I, Vacek S, Treštík M, Cukor J (2018). Effects of silver fir (Abies alba Mill.) on the humus forms in Norway spruce (Picea abies (L.) H. Karst.) stands. Journal of Forest Science 64 (6): 245-250. - doi: 10.17221/19/2018-JFS

Prietzel J, Bachmann A (2011). Changes in soil organic $\mathrm{C}$ and $\mathrm{N}$ stocks after forest transformation from Norway spruce and Scots pine into Douglas fir, Douglas fir/spruce, or European beech stands at different sites in Southern Germany. Forest Ecology and Management 269: 134-148. - doi: 10.1016/j.foreco.2011.12.034

Prudhomme GO, Lamhamedi MS, Benomar L, Rainville A, DeBlois J, Bousquet J, Beaulieu J (2017). Ecophysiology and growth of white spruce seedlings from various seed sources along a climatic gradient support the need for assisted migration. Frontiers in Plant Science 8: 2214. - doi: 10.3389/fpls.2017.02214

Šegota T, Filipčić A (2003). Köppenova podjela klima i Hrvatsko nazivlje [Köppen's classification of climates and the problem of corresponding Croatian terminology]. Geoadria 8 (1): 17-37. [in Croatian] - doi: 10.15291/geoadria.93 Smal H, Olszewska M (2008). The effect of af- forestation with Scots pine (Pinus sylvestris L.) of sandy post arable soils on their selected properties. II. Reaction, carbon, nitrogen and phosphorus. Plant and Soil 305: 171-187. - doi: 10.1007/s11104-008-9538-z

Swift MJ, Heal OW, Anderson JM (1979). Decomposition in terrestrial ecosystems. Blackwell Scientific Publications. Oxford, UK, pp. 372. [online] URL: http://books.google.com/books?id=h SWMkhdSfPAC

Vanmechelen L, Groenemans R, Van Ranst E (1997). Forest soil conditions in Europe. Results of a large scale soil survey. Technical Report, EC, UN/ECE, Ministry of the Flemish Community, Brussels, Belgium and Geneva, Switzerland, pp. 254.

Vesterdal L, Schmidt IK, Callesen I, Nilsson LO, Gundersen P (2008). Carbon and nitrogen in forest floor and mineral soil under six common European tree species. Forest Ecology and Management 255: 35-48. - doi: 10.1016/j.foreco. 2007.08.015

Wood M (1995). Environmental soil biology. In: "Soil formation and development" ( $\left.2^{\text {nd }} e d n\right)$. Springer, Netherlands, pp. 66-97. [online] URL: http://books.google.com/books?id=G_EkBAAA QBAJ

\section{Supplementary Material}

Tab. S1 - Chemical properties of soil in natural stands (control) and Norway spruce plantations.

Link: Perkovic_3023@supploo1.pdf 